DOI 10.31558/2307-2318.2019.1.3

УДК 331.5

Волянська-Савчук Л.В., к.е.н., доцент кафедри управління персоналом і економіки праці Хмельницького національного університету

Красовський В.О., студент кафедри управління персоналом і економіки праці Хмельницького національного університету

\title{
ТЕОРЕТИЧНІ ЗАСАДИ РИНКУ ПРАЦІ В ЕКОНОМІЧНІЙ СИСТЕМІ
}

Ринок праці є невід'ємною складовою частиною загальноекономічного ринкового механізму. Він характеризується як одне з найбільш складних соціально-економічних явищ суспільства, в якому відбиваються всі сторони його життєдіяльності, проявляється вся різноманітність його інтересів та протиріч. Тому процес його функціонування постійно знаходиться у колі зору держави, оскільки відтворення такого товару, як робоча сила - це відтворення трудових ресурсів і в цілому продуктивних сил суспільства.

Ключові слова: ринок, ринок праці, ринок робочої сили, моделі ринку праці, суб'єкти формування системи соціально-трудових відносин.

\section{Волянская-Савчук Л.В., Красовский В.О. \\ ТЕОРЕТИЧЕСКИЕ ПРИНЦИПЫ РЫНКА ТРУДА В ЭКОНОМИЧЕСКОЙ СИСТЕМЕ}

Рынок труда является неотъемлемой составной частью общеэкономического рыночного механизма. Он характеризуется как одно из наиболее сложных социальноэкономических явлений общества, в котором отражаются все стороны его жизнедеятельности, проявляется все разнообразие его интересов и противоречий. Поэтому процесс его функционирования постоянно находится в поле зрения государства, поскольку воспроизведения такого товара, как рабочая сила - это воспроизводство трудовых ресурсов и в целом производительных сил общества.

Ключевые слова: рынок, рынок труда, рынок рабочей силы, модели рынка труда, субъекты формирования системы социально-трудовых отношений.

\section{Volianska-Savchuk L., Krasovskyi V. \\ THEORETICAL PRINCIPLES OF THE LABOR MARKET IN THE ECONOMIC SYSTEM}

The labor market is an integral part of the general economic market mechanism. He is characterized as one of the most complex socio-economic phenomena of society, which reflects all aspects of his life, manifested the whole variety of his interests and contradictions. Therefore, the process of its functioning is constantly in the state view, since the reproduction of such a product as labor is the reproduction of labor resources and in general the productive forces of society.

Key words: market, labor market, labor market, labor market model, subjects of the formation of the system of social and labor relations.

Постановка проблеми. Ефективний розвиток економіки держави залежить від успішного функціонування системи ринків. Вони забезпечують матеріальні, фінансові, інформаційні та міграційні потоки, за допомогою яких здійснюється їх взаємодія. Особливе місце в системі ринків належить ринку праці. Ринок праці, будучи складним соціально-економічним поняттям, піддається постійним науковим дослідженням як 
вітчизняними, так і закордонними науковцями. За своїм змістом він є багатогранним, суперечливим, неоднорідним. У зв'язку із цим, актуалізується питання ретроспективного аналізу дефініції поняття «ринок праці».

Аналіз останніх досліджень. Серед теоретиків ринку праці за основу обрано фундаментальні праці видатних представників економічної думки - А. Сміта, К. Маркса та ін. Серед вітчизняних вчених-економістів та практиків, які займаються дослідженням й розв'язанням проблем функціонування ринків праці, використано роботи таких дослідників, як Е. Лібанова, А. Колот, В. Петюх, О. Грішнова, О. Іляш, А. Калина, М. Ажнюк, О. Передрій, І. Швець та ін. В економічній літературі знаходять своє відображення проблеми регулювання ринку праці. Особливо слід відзначити роботи Д. Гелбрейта, Р. Еренбурга, Д. Кейнса, К. Макконнелла, К. Маркса, А. Оукена, П. Самуельсона, а також українських вчених зі світовим ім'ям: І. Вернадського, С. Подолинського, М. Туган-Барановського. Значний доробок у розробку теоретичних основ регулювання зайнятості внесли такі відомі вітчизняні вчені, як Л.І. Антошкіна, А.С. Ачкасов, А.В. Базилюк, Д.П. Богиня, І.К. Бондар, В.С. Васильченко, О.А. Грішнова, Т.А. Заяць, С.М. Злупко, А.М. Колот, Ю.М. Краснов, О.М. Кузнєцова, В.М. Лич, Е.М. Лібанова, О.Ф. Новикова, О.Ю. Рудченко та ін. Окремі аспекти інноваційних чинників зайнятості розглядали у своїх наукових працях Б.О. Баласинович, Л.С. Лісогор, В.В. Онікієнко, О.А. Попова, В.І. Чижова.

Формулювання цілей статті. Мета статті - створення організаційноекономічного механізму регулювання ринку праці, що забезпечує ефективне використання робочої сили, запобігає масовому безробіттю та створює умови для запровадження необхідного рівня соціального захисту населення..

Виклад основного матеріалу. В сучасній економічній літературі не існує єдиної думки щодо визначення поняття «ринок праці», тим більше поряд із цим поняттям існує ще поняття «ринок робочої сили». Існують думки, що ці поняття або тотожні, або різні. Різні погляди авторів на ці поняття визначаються, насамперед, метою дослідження конкретних аспектів трудової діяльності. Тотожність цих понять пояснює Буланов В. С., стверджуючи: «...ринок робочої сили можна назвати ринком функціонуючої робочої сили, або ринком праці. Ринок праці - це товарно-грошові відносини, що пов'язані, поперше, з попитом на робочу силу, визначеним у свою чергу попитом на продукт того або іншого товару в суспільстві, по-друге, з використанням професійних здібностей i ïх винагородою, по-третє, з часом використання робочої сили. Тут об'єктом обміну є функціонуюча здатність до праці, чи функціонуюча робоча сила. В такому випадку можна говорити про тотожність понять «ринок праці» $\mathrm{i}$ «ринок робочої сили (функціонуючої робочої сили)» [1]. Таке трактування ринку праці характерне для умов, що забезпечують підвищення продуктивності праці, що, у свою чергу, буде направлено на підвищення оплати праці зайнятих у виробництві, на професійне зростання, на підвищення життєвого рівня населення і на гідне проведення часу у вільний від роботи час.

Т. Тихомирова переконливо доводить, що ринок праці є ринком зобов'язань, які відображені у договорі найму [2, с. 62]. При укладенні такого договору працівник зобов'язується, використовуючи свою робочу силу, виконувати передбачену для нього роботу і результат праці передати працедавцю.

Недоліком підходу автора є те, що Т. Тихомирова обмежує ринок праці моментом укладення договору найму, коли, за їі переконаннями, і закінчуються ринкові відносини. На думку автора, реалізація договору найму здійснюється вже на підприємстві, у сфері виробництва і за законами виробництва. Аналогічний підхід розглядається в роботах А. 
Е. Котляра, А. I. Рофе, Б. Г. Збишко, В. В. Ішина, де вказується, що особи, охоплені стабільною зайнятістю, не представлені на ринку праці, оскільки їхня праця, будучи купленою, реалізується у сфері виробництва. Головним аргументом авторів $\epsilon$ необхідність розмежування сфери виробництва та сфери обігу.

Ринок - це сукупність соціально-економічних відносин у сфері обміну, за допомогою яких здійснюється купівля-продаж товарів і остаточне визнання їхньої суспільної цінності. Це центральний елемент товарного виробництва, тому що ринок $\epsilon$ панівним і визначальним способом зв'язку між відокремленими виробниками на основі суспільного поділу праці.

Робоча сила як сукупність фізичних i духовних здібностей людини, які використовуються нею у процесі створення благ і послуг, є товар, що продається і купується на відповідному ринку - ринку робочої сили.

Ринок праці - особлива економічна категорія, яка охоплює оплачувану зайнятість, до якої належать претенденти на робоче місце і всі зайняті, крім тих, що навчаються, i домашніх працівників, які ведуть натуральне господарство.

Як економічна категорія ринок праці є складною системою відносин щодо обміну індивідуальних здібностей до праці на фонд життєвих засобів, необхідних для відтворення робочої сили і розміщення працівників у системі суспільного поділу праці за законами товарного виробництва і обігу [2, с. 121].

Враховуючи багатогранність понять «ринок праці» та «ринок робочої сили», визначено єдність і протиріччя (таблиця 1) [3, с. 121].

Таблиця 1

Протиріччя та сдність ринку праці та ринку робочої сили

\begin{tabular}{|c|c|c|}
\hline & Протиріччя & Сдність \\
\hline Ринок праці & \begin{tabular}{l}
\multicolumn{2}{c}{ Відносяться тільки зайняті } \\
працівники сфери матеріального та \\
нематеріального виробництва, але не \\
безробітні; тільки конкретні об'єкти \\
ринку праці, що зафіксовані в трудових \\
договорах; співвідношення між \\
кількістю зареєстрованих громадян, \\
незайнятих трудовою діяльністю, до \\
потреби підприємств у працівниках на \\
заміщення вільних робочих місць
\end{tabular} & \begin{tabular}{lr}
\multicolumn{3}{l}{ інфраструктура ринків: біржі } \\
праці та зайнятості, система \\
регіонального \\
загальнодержавного та \\
пропозицій та попиту, слу-ку \\
організації гро-мадських робіт, \\
пере-підготовки кадрів тощо; \\
прискорення міграційних процесів; \\
сегментація та гнучкість ринків; \\
спів-відношення між профе-сійною
\end{tabular} \\
\hline $\begin{array}{c}\text { Ринок робочої } \\
\text { сили }\end{array}$ & $\begin{array}{l}\text { Відносяться зайняті працівники сфери } \\
\text { матеріального і і нематеріального } \\
\text { виробництва та безробітні; в структурну } \\
\text { класифікацію вартості робочої сили } \\
\text { включено не тільки конкретних об'єктів } \\
\text { ринку праці, що зафіксовані в трудових } \\
\text { договорах, але ж і оплату щорічних } \\
\text { відпусток за вислугу років, профспілкову } \\
\text { діяльність, вихідну допомогу, соціальне } \\
\text { забезпечення; співвідно-шення між } \\
\text { трудовими ресурсами та робочими } \\
\text { місцями, міграційні процеси населення } \\
\text { та ін. }\end{array}$ & 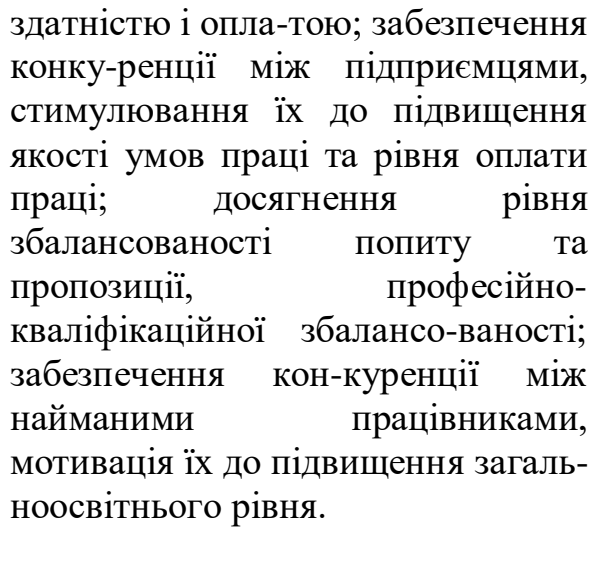 \\
\hline
\end{tabular}

Сформовані протиріччя та єдність дозволяють визначити, що об'єктом ринку праці є праця, а об'єктом ринку робочої сили є робоча сила, яка наділена фізичними, 
професійними, порядними, чесними, комунікабельними характеристиками. Моральноетичні аспекти не $\epsilon$ предметом обміну на ринку, але впливають на нього. Тому перевага надаватиметься ринку праці.

Деякі автори вважають, що ринок праці - пережиток минулого і в сучасних умовах його бути не може. Так, В. А. Каменецкий і В. П. Патрікеєв стверджують: «Ринку праці не може просто бути тому, що з ліквідацією права рабовласництва зникає і право розглядати саму людину або будь-який його орган або властивості в якості «товару» [3, с. 255]. Подібний підхід позбавляє можливості аналізу та прогнозу всіх складових, пов'язаних із забезпеченням процесу виробництва таким основоположним елементом, як праця, завдяки якому створюються вартість і додаткова вартість.

У зв'язку з різними підходами у визначенні меж ринку праці виникли два трактування поняття «ринок праці» - розширене і вузьке. Традиційне визначення ринку праці зводиться до того, що об'єктом купівлі-продажу є робоча сила людини, ії здібність до праці, що набуває форми товару [4]. Ускладнення суспільних взаємозв'язків, необхідність системного вивчення діючих елементів економіки сприяли тому, що в останнє десятиліття з'явився новий, ширший погляд на категорію «ринок праці».

Ринок праці в широкому розумінні розглядається як система суспільних відносин, соціальних норм і інститутів, що забезпечують на основі дотримання загальноприйнятих прав і свобод людини формування, обмін за ціною, визначуваною співвідношенням попиту та пропозиції, і використовування робочої сили [5, с. 18]. 3 наведеним розширеним трактуванням ринку праці категорично не погоджується О. Е. Котляр. На його думку, такий підхід не передбачає відмінностей між такими специфічними сферами діяльності, як виробництво і обіг; не враховується непотрібність перебування на ринку праці людей, які здійснили акт купівлі-продажу робочої сили; маскуються відмінності між зайнятими і безробітними. 3 точки зору О. Е. Котляра, «вказаний підхід вносить плутанину в питання про співвідношення політики зайнятості та політики на ринку праці» $[6$, с. 240].

А. В. Топілін ще ширше розглядає відносини на ринку праці, розуміючи під ними «систему суспільних відносин між працівником і працедавцем на всіх стадіях відтворення робочої сили: іiї виробництва (соціально-демографічний аспект, нова робоча сила), обміну (акт купівлі-продажу), розподілу (за допомогою соціального, професійного і територіального переміщення робочої сили) і використовування у сфері праці» [7, с. 11]. Вважається недостатньо обгрунтованим відносити всю сферу відтворення робочої сили до ринку праці. Очевидно, що формування робочої сили, що відбувається, наприклад, у процесі навчання, буде значною мірою орієнтовано на стан (поточний і перспективний) ринку праці.

П. Г. Єрмішин заперечує єдність ринку праці, вказуючи, що «єдиного для всієї економіки ринку праці не існує. Він поділяється за професіями, галузями, територіями» [8]. Можна погодитися, що такий підхід не дасть можливості надалі здійснювати регулювання ринку праці в цілому, в масштабах країни, звівши його до розрізнених дій галузевих міністерств або органів виконавчої влади суб'єктів України.

Розділяємо думку про те, що жодне з наведених визначень (вузького і широкого трактування) не є «вірним» або «невірним» - кожне 3 них може бути корисне залежно від контексту, тобто від того, які процеси вивчаються, які завдання порушуються і які висновки та рекомендації передбачається розробити. На основі формулювань поняття «ринок праці» можна виділити декілька методологічних підходів до сутності ринку праці: товарний ринок, соціально-економічні відносини, система, сфера, механізм, простір тощо. К. Маркс розглядав ринок праці як товарний ринок, з обмовкою, про те, 
що даний підхід є наслідком капіталістичного відношення до праці і робочої сили, вірніше, наслідком фактичного стану речей [9, с. 161]. Еренберг Р. Дж., Р. С. Сміт ринок праці розглядають як сегмент національної економіки, який забезпечує людей роботою і координує відносини у сфері праці [10, с. 33]. Ряд науковців ринок праці розглядають як соціально-економічні відносини між його суб'єктами, як систему, механізм дій елементів ринкових відносин (таблиця 2).

Таблиця 2

Авторські дефініції поняття «ринок праці»

\begin{tabular}{|c|c|}
\hline Визначення & Автор \\
\hline 1 & 2 \\
\hline \multicolumn{2}{|l|}{ як соціально-економічних відносин } \\
\hline $\begin{array}{l}\text { Ринок праці - це сукупність соціально-трудових відносин, що виникають } \\
\text { iз приводу способів залучення індивідуальної праці в процес виробництва, } \\
\text { способів координації та використання праці та ії оцінки, в які ступають } \\
\text { працівники, надаючи трудові послуги і підприємці, купуючи та } \\
\text { використовуючи їх }\end{array}$ & $\begin{array}{l}\text { Колот А. М } \\
{[11, \text { с. 239]. }}\end{array}$ \\
\hline $\begin{array}{l}\text { Ринок праці - це соціально-економічна категорія, яка характеризує } \\
\text { відносини людей, що проявляються в процесі найму, оцінки, звільненя } \\
\text { працівників і встановлення розмірів компенсацій за використану робочу } \\
\text { силу залежно від ряду факторів }\end{array}$ & $\begin{array}{l}\text { Петюх В. М. } \\
{[12, \text { c. } 54] .}\end{array}$ \\
\hline $\begin{array}{l}\text { Ринок праці - це сукупність економічних відносин, за допомогою яких } \\
\text { здійснюється обіг суспільного продукту в товарно-грошовій формі }\end{array}$ & $\begin{array}{l}\text { Яковець Ю. В. } \\
{[13, \text { с. } 122]}\end{array}$ \\
\hline $\begin{array}{l}\text { Ринок праці - сукупність соціально-економічних відносин між державою, } \\
\text { роботодавцями та працівниками } 3 \text { питань купівлі-продажу робочої сили, } \\
\text { навчання працівників і використання їх у процесі виробництва }\end{array}$ & $\begin{array}{l}\text { Єгоршин А. П. } \\
{[14, \text { с 9] }}\end{array}$ \\
\hline $\begin{array}{l}\text { Ринок праці - це комплекс відносин } 3 \text { приводу умов наймання } \\
\text { використання робочої сили, в який ходять відносини попиту та пропозиції } \\
\text { робочої сили, ціни праці, оплати понаднормової праці, страхування } \\
\text { приводу тимчасової непрацездатності, безробіття тощо }\end{array}$ & $\begin{array}{l}\text { Мiтус O. O. } \\
{[15]}\end{array}$ \\
\hline \multicolumn{2}{|l|}{ як система } \\
\hline $\begin{array}{l}\text { Ринок праці - це система соціально-економічних відносин між } \\
\text { працівниками і роботодавцями з приводу купівлі-продажу товару «робоча } \\
\text { сила», яка пронизує усі фази відтворення працівника і ефективного } \\
\text { використання юго трудового потенціалу; це сфера, на якій встановлюється } \\
\text { певне співвідношення попиту і пропозиції на послуги робочої сили, ії ціни } \\
\text { та умов праці, забезпечення балансу інтересів працівників і роботодавців, } \\
\text { державна підтримка непрацездатних громадян, яка регулюється за } \\
\text { допомогою соціальних, правових і юридичних норм та інститутів }\end{array}$ & $\begin{array}{l}\text { Чернявська Ю.Б. } \\
{[16,155] .}\end{array}$ \\
\hline $\begin{array}{l}\text { Ринок праці - це система суспільних відносин, пов'язаних із наймом і } \\
\text { пропозицією праці, тобто } 3 \text { їі купівлею і продажем праці; це також } \\
\text { економічний простір - сфера працевлаштування, де взаємодіють покупці та } \\
\text { продавці праці }\end{array}$ & $\begin{array}{l}\text { Грішнова О.А. } \\
{[17, \text { с. } 77]}\end{array}$ \\
\hline $\begin{array}{l}\text { Ринок - праці - це система суспільних відносин з погодженими інтересами } \\
\text { роботодавців і тими, кого наймають як робочу силу }\end{array}$ & $\begin{array}{c}\text { Ссінова Н. І. } \\
{[18, \text { с 122] }}\end{array}$ \\
\hline
\end{tabular}


Продовження таблиці 2

\begin{tabular}{|c|c|}
\hline 1 & 2 \\
\hline $\begin{array}{l}\text { Ринок праці - це система соціально-економічних відносин між } \\
\text { роботодавцями - власниками засобів виробництва - та населенням - } \\
\text { власниками робочої сили - щодо задоволення попиту перших на працю, а } \\
\text { інших - на робочі місця, які є їхнім джерелом засобів існування }\end{array}$ & $\begin{array}{l}\text { Лібанова Е. М. [19, } \\
\text { с. 12]. }\end{array}$ \\
\hline \multicolumn{2}{|l|}{ як механізм дії елементів ринкових відносин } \\
\hline $\begin{array}{l}\text { Ринок праці - це механізм, що забезпечує узгодження ціни і умов праці між } \\
\text { роботодавцями і найманими працівниками та регулює іï попит та } \\
\text { пропозицію }\end{array}$ & $\begin{array}{l}\text { Грішнова О.А. [17. } \\
\text { с 77]. }\end{array}$ \\
\hline $\begin{array}{l}\text { Ринок праці - це система економічних механізмів, норм та інститутів, що } \\
\text { забезпечують відтворення робочої і використання праці }\end{array}$ & $\begin{array}{l}\text { Калина А. В. } \\
\text { [20, с 38]. }\end{array}$ \\
\hline $\begin{array}{l}\text { Ринок праці - сукупність механізмів, які забезпечують координацію } \\
\text { попиту та пропозиції праці, купівлю/продаж робочої сили, визначення ії } \\
\text { вартості, організацію оплати праці, соціальну опіку через підприємницькі } \\
\text { структури }\end{array}$ & $\begin{array}{l}\text { Швайка Л. А. } \\
\text { [21, с 229]. }\end{array}$ \\
\hline $\begin{array}{l}\text { Ринок праці - це працюючий у рамках певного економічного простору } \\
\text { механізм взаємодії між роботодавцями а найманими працівниками, що } \\
\text { виражає економічні та правові відносини між ними }\end{array}$ & $\begin{array}{l}\text { Костин П. А. } \\
{[22, \text { с. } 30] .}\end{array}$ \\
\hline
\end{tabular}

Крім вищенаведених визначень, деякі вчені розглядають ринок праці як економічний простір, що не має чітко позначених меж і розвивається за рахунок міграційних процесів [23, с. 58] і на якому в результаті конкуренції між економічними агентами через механізм попиту та пропозиції встановлюється певний обсяг зайнятості та рівень оплати праці. Інші вчені ринок праці розглядають як сферу, в якій протистоять один одному, з одного боку, особи, що шукають роботу, в тому числі безробітні, з іншого - роботодавці, які мають незайняті робочі місця на підприємствах, в організаціях, між якими укладаються трудові договори, визначається рівень заробітної плати.

Підводячи підсумок проведеному аналізу існуючих трактувань поняття «ринок праці», враховуючи різноманіття існуючих форм праці і специфічність робочої сили, що виступає як одна із сторін і бере участь в обміні на ринку праці, пропонується в межах наукового дослідження ринок праці розглядати як система трудових відносин, що відображають рівень соціального розвитку і досягнутий баланс інтересів між суб'єктами: працедавцями, працівниками, державою, профспілками і посередниками, комплексна поведінка яких розглядається через функції розподільну, регулятивну, інформаційну, посередницьку, стимулюючу, оздоровчу, головною з яких виділена розподільна функція, яка відображає усі соціально-економічні явища [24, с. 58].

Аналіз наукової літератури засвідчує, що проблематика ринку праці знаходиться постійно у полі зору науковців, адже стан ринку праці слугує індикатором успішності соціальних та економічних реформ. Разом з тим, теоретичний аналіз засвідчує широке коло наукових підходів щодо тлумачення сутності категорії «ринок праці», серед яких найбільш поширеними є такі:

- це інститут або механізм, що поєднує, зводить разом продавців і покупців 
товару «робоча сила»;

- це система соціально-економічних відносин між роботодавцями - власниками засобів виробництва - та населенням - власниками робочої сили - щодо задоволення попиту перших на працю, а других - на робочі місця, які є їх джерелом засобів існування;

- це система обміну індивідуальних здібностей до праці на фонд життєвих цінносте^, , необхідних для відтворення робочої сили;

- це особливий ринок, на якому відбувається продаж послуг праці в якості специфічного товару, що дозволяе найманому працівнику на умовах договору (контракту) виконати певний обсяг роботи (трудових послуг) певної якості упродовж необхідного часу, отримуючи дохід;

- це система особливої взаємодії ринкового попиту і пропозиції, результатом якої $\epsilon$ певний обсяг зайнятості та ціна послуг праці; це є узгодження інтересів роботодавців $і$ реальних та потенційних працівників щодо обсягів та умов використання праці, основними елементами якого $є$ попит, пропозиція, ціна, конкуренція, резервування праці та трудова мобільність.

Зауважимо, що наведені тлумачення не суперечать один одному, а лише доповнюють та збагачують розуміння змісту цієї категорії. Між тим розмаїття наукових уявлень говорить про те, що теорія ринку праці поки що знаходиться у стані розвитку. Розбіжності у підходах науковців існують і тому нагальною потребою $є$ продовження наукових пошуків у напрямі визначення глибинної сутності ринку праці, аспектів його сучасного розвитку.

В той же час, одним із традиційних філософських способів вивчення різних категорій i понять, поруч 3 онтологічним i антропологічним, $\epsilon$ гносеологічний. Зосередимо увагу на можливостях гносеологічного аналізу проблематики ринку праці.

Традиційно в науковій літературі виокремлюють три основні моделі ринку праці: ліберальну, патерналістську та соціал-демократичну (рисунок 1) [25, с. 475].

Гносеологія (давньогрец. «гносис» - пізнання; «логос» - учення, наука) в традиційному сенсі $\epsilon$ таким типом оперування значеннями, який націлений на встановлення смислів, що мають відношення до з'ясування феномена взаємодії між думкою і фактом, думкою і подією, думкою і сутністю буття, яку вона осмислює. Іншими словами, гносеологічний аналіз передбачає обгрунтування реальності існування об'єкта, його відповідності тим властивостям, формам, ознакам, які йому приписують.

Гносеологічний підхід до аналізу поняття ринку праці стає актуальним в умовах необхідності формування міждисциплінарної парадигми його дослідження. Ринок праці частіше стає предметом вивчення економістів - з огляду на його значення в економічних (виробничих) процесах. Має місце вивчення ринку праці в державному управлінні - як об'єкта впливу, чинника соціально-економічного розвитку країни, регіонів, поселень. Інші дисциплінарні ракурси, кожен по-своєму, розкривають специфіку ринку праці як категорії, що позначає «щось».

Гносеологічний аналіз поняття ринку праці змушує замислитись над тим, чим у дійсності він є: місцем зустрічі роботодавця і працівника - більш реальне уявлення про ринок як фізичний об'єкт; механізмом, системою - абстрактне уявлення про ринок як те, що виникає у ході взаємодій різних суб'єктів. Так само можуть виникати протиріччя 3 приводу прив'язки ринку до певних просторових умов. У різних просторово-часових вимірах ринок праці може проявлятись абсолютно по-різному та більше того - втрачати свої традиційні ознаки (взяти, для прикладу, ринок праці моноспеціалізованих міст; для них ринок праці не відповідає усім ознакам, а у випадку кризи галузі фактично втрачає свою функціональність). 

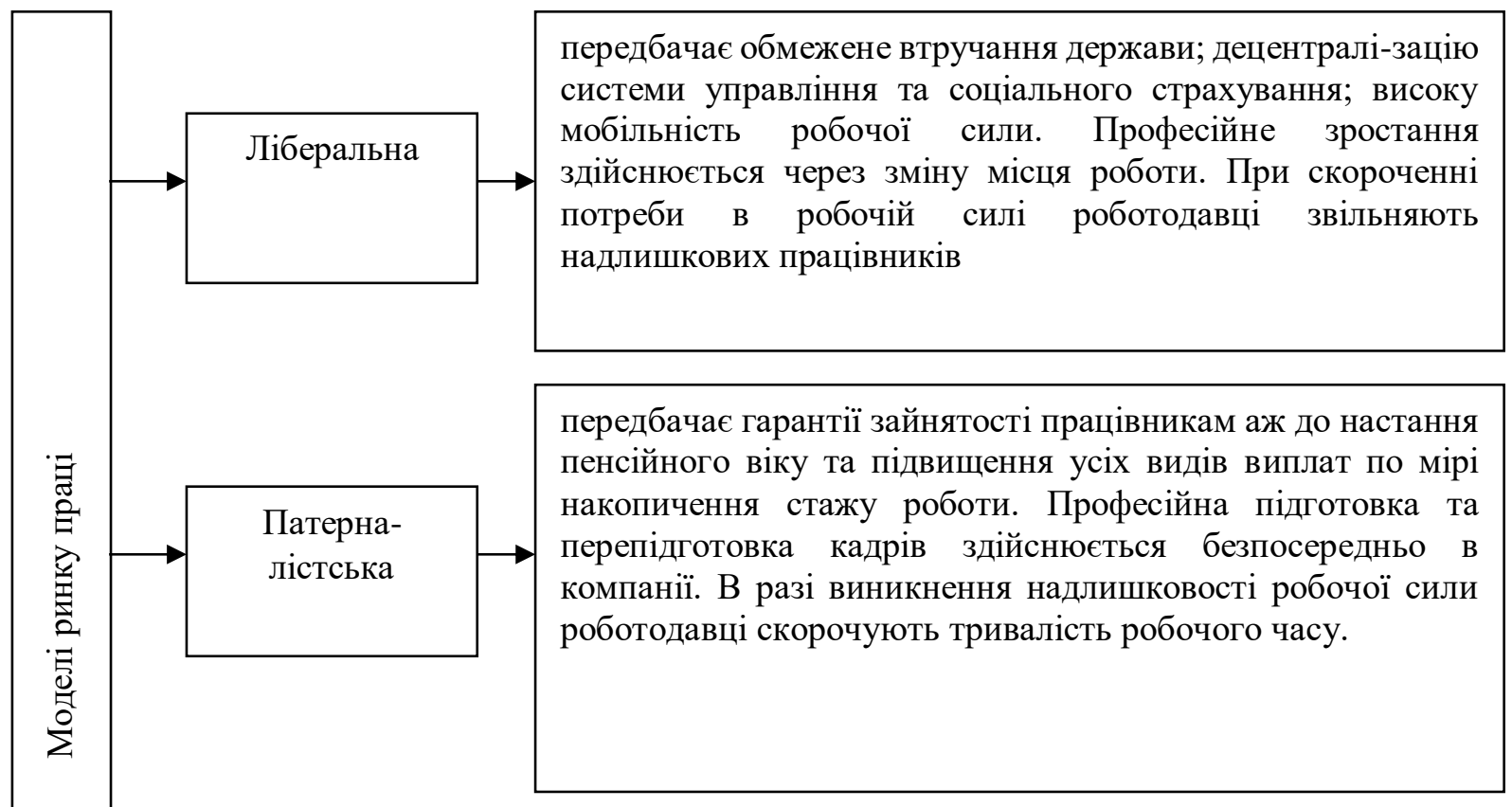

активна державна політика щодо ринку праці, спрямована на забезпечення якомога повнішої зайнятості, соціальний захист неконкурентоспромож-

них працівників та секторів економіки, рівність оплати однакової праці незалежно від фінансового стану підприємства.

\section{Рисунок 1 - Основні моделі ринку праці}

Актуалізація філософських засад вивчення ринку праці як, насамперед, економічної категорії зумовлена необхідністю формування нового погляду на процеси його розвитку. Тому формування міждисциплінарної парадигми дослідження ринку праці є важливим завданням, яке дозволяє науковцям чітко розділяти функціональну значимість даної категорії у різних галузях знань (рисунок 2) [26, с. 130].

У гносеологічному вимірі центральним є об'єкт пізнання - як фрагмент (частина) будь-якої реальності (природної, соціальної, суб'єктивної, розумової, душевної та ін.), який не збігається у цей момент 3 інтелектом, що пізнає, та на який спрямована пізнавальна активність.

У нашому випадку об'єктом пізнання є ринок праці (таблиця 3) [27, с. 164].

Дефініція ринку праці в економічному контексті диференціюється між його розглядом в межах різних аспектів, зокрема як:

- суспільно-економічної форми руху людських ресурсів (інтелектуально-трудового потенціалу);

- сфери формування попиту і пропозиції на робочу силу;

- механізму виявлення та погодження попиту і пропозиції на робочу силу;

- механізму ефективного використання інтелектуально-трудового потенціалу країни, регіонів, окремих поселень (муніципальних утворень); 


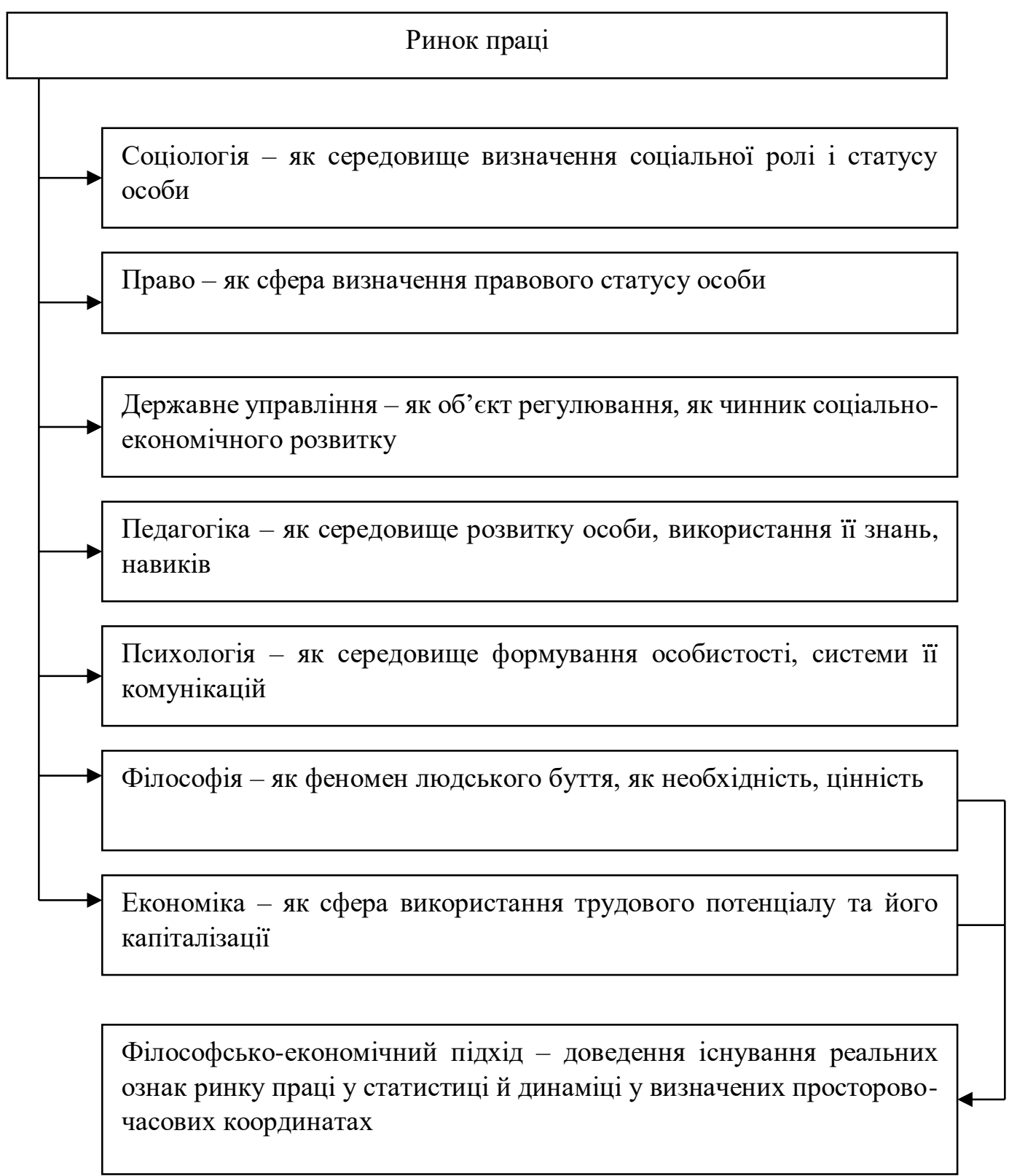

\section{Рисунок 2 - Міждисциплінарна парадигма визначення сутності ринку праці}

- частини економічної, ринкової системи;

- системи відносин між роботодавцями і працездатним населенням, соціальних норм, що забезпечують відтворення, обмін і використання праці;

- системи відносин, де на основі поєднання ринкового та державного механізмів регулювання відбуваються трансформаційні зміни у використанні інтелектуальнотрудового потенціалу.

Виходячи 3 аналізу наведених визначень, стає зрозумілим, наскільки багатогранним є поняття, ринку праці, його вплив на різноманітні економічні та соціальні явища. Вагома соціальна та економічна роль ринку праці у розвитку економіки та суспільства стимулює науковців ще більш глибоко досліджувати особливості ринку праці, фокусуючи увагу на різних актуальних, на їхній погляд, аспектах. 
Таблиця 3

Основні гносеологічні питання зі специфікою вивчення ринку праці

\begin{tabular}{|c|c|l|}
\hline № & $\begin{array}{c}\text { Основоположні } \\
\text { питання гносеології }\end{array}$ & \multicolumn{1}{|c|}{ Поняття у сфері вивчення ринку праці } \\
\hline 1 & Об'єкт & Ринок праці \\
\hline 2 & Суб'єкт & $\begin{array}{l}\text { Інститути-суб'єкти (роботодавець (у т.ч. самозайнятий), працівник, } \\
\text { посередник), інститути-регулятори (державні, громадські) }\end{array}$ \\
\hline 3 & Пізнаваність & $\begin{array}{l}\text { Ознаки ринку праці (кон'юнктура: попит, пропозиція, ціна; } \\
\text { структура, інфраструктура, конкуренція), функціональність }\end{array}$ \\
\hline 4 & Відображення & $\begin{array}{l}\text { Просторовий вимір: світовий, транскордонний, національний, } \\
\text { регіональний, локальний ринок праці. Часовий вимір: постійний, } \\
\text { тимчасовий }\end{array}$ \\
\hline 5 & Діалектика & $\begin{array}{l}\text { Розвиток ринку праці (зміна, трансформація, модернізація, } \\
\text { інноватизація і т.д.) }\end{array}$ \\
\hline 6 & Практика & $\begin{array}{l}\text { Праця, трудова діяльність, економічна активність, зайнятість, } \\
\text { самозайнятість, безробіття, непрацездатність і т.д. }\end{array}$ \\
\hline 7 & Історизм & $\begin{array}{l}\text { Становлення ринку, ретроспектива розвитку (поєднання з } \\
\text { діалектикою) }\end{array}$ \\
\hline 8 & Істина & Цінність, ціль, результат \\
\hline
\end{tabular}

Орієнтуючись на філософсько-економічний підхід до розгляду ринку праці, важливо зрозуміти реальність його існування. Частково це дозволяє зробити формування його інституційної основи - суб'єкта у гносеології. 3 теорії пізнання відомо, що суб'єкт та об'єкт співвідносні: об'єкт набуває характеристик саме об'єкта лише у відношенні до певного суб'єкта, тоді як останній виявляє себе лише через дію(вплив) на певний об'єкт. Відповідно якщо за об'єкт брати ринок праці, то суб'єктами будуть інститути, які діють на цьому ринку.

Вважаємо, що з позицій гносеологічного аналізу ринок праці слід розглядати як систему соціально-трудових відносин, які виникають між конкретними інститутами. Таким чином, реальні учасники ринку підтверджують його існування. Допоки вони будуть комунікувати між собою, в основі чого лежить певний інтерес, доти ринок праці буде існувати (таблиця 4) [28, с. 277].

В результаті систематизації наукових уявлень про сутність ринку праці відповідно до міждисциплінарної парадигми дослідження ринку праці, було сформовано філософсько-економічний підхід до розуміння сутності ринку праці шляхом доведення існування реальних ознак ринку праці у статиці й динаміці у визначених просторовочасових координатах.

Гносеологічний аналіз поняття ринку праці доводить необхідність виявлення суб'єктів, які на ньому діють. У нашому випадку - це інститути, які формують систему соціально-трудових відносин, що пов'язані з наймом, використанням, відтворенням робочої сили та спрямовані на забезпечення високого рівня й якості життя особистості, колективів та суспільства в цілому. Сучасні проблеми та особливості функціонування ринку праці України віддзеркалюють глибинні внутрішні суперечності та особливості, притаманні національній економіці, сфері зайнятості через незавершеність структурної перебудови економіки, політичні потрясіння, слабку керованість соціальноекономічною політикою у сфері праці, спотворення соціальних цінностей, слабкість механізмів державного регулювання, недосконалість маркетингових технологій. 
Таблиця 4

Суб'скти формування системи соціально-трудових відносин на ринку праці, що доводять реальність його існування

\begin{tabular}{|c|c|c|c|}
\hline $\begin{array}{l}\text { № } \\
\text { 3/ח }\end{array}$ & Інститути & Основні види & Основний інтерес \\
\hline 1 & \multicolumn{3}{|c|}{ Інститути-суб 'єкти } \\
\hline 1.1 & $\begin{array}{l}\text { Роботода- } \\
\text { вець }\end{array}$ & $\begin{array}{l}\text { Юридичні особи, фізичні } \\
\text { особи (самозайняті) }\end{array}$ & $\begin{array}{c}\text { Одержання прибутку у ході використання } \\
\text { інтелектуально-трудового потенціалу -влас- } \\
\text { ного і залучених працівників }\end{array}$ \\
\hline 1.2 & Працівник & $\begin{array}{c}\text { Зайнятий, найманий, штат- } \\
\text { ний, безкоштовно працюю- } \\
\text { чий, тимчасово незайнятий, } \\
\text { безробітний }\end{array}$ & $\begin{array}{c}\text { Одержання доходу в ході використання } \\
\text { особистого інтелектуально-трудового потен- } \\
\text { ціалу, в тому числі з можливістю подальшого } \\
\text { інвестування у свій людський капітал }\end{array}$ \\
\hline 1.3 & Посередник & $\begin{array}{c}\text { Рекрутингові, страхові, бан- } \\
\text { ківські та ін. компанії, освіт- } \\
\text { ні установи }\end{array}$ & $\begin{array}{c}\text { Одержання прибутку від надання затребу- } \\
\text { ваних суб'єктам ринку праці послуг, обслуго- } \\
\text { вування їхніх доходів, сприяння розвитку } \\
\text { інтелектуально-трудового потенціалу }\end{array}$ \\
\hline 2 & \multicolumn{3}{|c|}{ Інститути-регулятори } \\
\hline 2.1 & Державні & $\begin{array}{c}\text { Профільні органи державної } \\
\text { влади, у т.ч. державна } \\
\text { служба зайнятості }\end{array}$ & $\begin{array}{c}\text { Оптимізація впливу ринку праці на } \\
\text { соціально-економічний розвиток країни } \\
\text { (регіонів) з прямим відображенням на подат- } \\
\text { кових платежах, рівнях зайнятості, конку- } \\
\text { ренттоспроможності бізнес-середовища; } \\
\text { соціальний захист і підтримка суб'єктів } \\
\text { ринку }\end{array}$ \\
\hline 2.2 & Громадські & $\begin{array}{c}\text { Форми самоорганізації } \\
\text { суб'єктів ринку (роботодав- } \\
\text { ців, працівників) }\end{array}$ & Консолідація зусиль для захисту інтересів \\
\hline 2.3 & Міжнародні & Міжнародні організації & $\begin{array}{c}\text { Контроль дотримання стандартів міжнарод- } \\
\text { ного трудового права }\end{array}$ \\
\hline
\end{tabular}

Висновки. Викладене свідчить про необхідність вдосконалення державного регулювання ринку праці, налагодження активного соціального діалогу для підвищення рівня офіційної зайнятості, забезпечення соціальної відповідальності держави та бізнесу за створення продуктивних робочих місць. Перспективи подальших наукових розробок мають бути пов'язані із розробкою державної стратегії розвитку національного ринку праці в умовах глобальних процесів та євроінтеграції.

\section{СПИСОК ВИКОРИСТАНИХ ДЖЕРЕЛ}

1. Людський розвиток регіонів України : аналіз та прогноз : монографія / за ред. Е.М. Лібанової. - К. : Ін-т демографії та соціальних досліджень НАН України , 2007. - 367 с. 2. Волянська-Савчук Л. В. Ринок праці: основні поняття та проблеми сьогодення / Л. В. Волянська-Савчук, А.Ю. Конопко // Приазовський економічний вісник. - 2018. - № 5 (10). - C. 299-304.

3. Волянська-Савчук Л. В. Зайнятість в ринковій економіці: понятійний апарат, фактори, основні тенденції для України / Л.В. Волянська-Савчук, О.М. Пітик // Zbiór artykułów naukowych. Konferencji Miedzynarodowej NaukowoPraktycznej "Economy. Zarządzanie. 
Badania podstawowe i stosowane: wyzwania i wyniki" (30.05.2017 - 31.05.2017) - Warszawa: Wydawca: Sp. z o.o. «Diamond trading tour», 2017. - c. 35-37.

4.Чернявська О.В. Ринок праці : навч. посіб. / О.В. Чернявська - К. : “Центр учбової літератури", 2013. - 522 с.

5. Васильченко В.С. Державне регулювання зайнятості : навч. посіб. / В.С. Васильченко - К. : КНЕУ 2003. - 200 c.

6. Маршавін Ю.М. Регулювання ринку праці України : теорія і практика системного підходу : монографія / Ю.М. Маршавін. - К. : Альтерпрес, 2011. - 396 с.

7.Жуковська А. Організація професійної орієнтації шкільної молоді : проблеми та шляхи їх вирішення / А. Жуковська, Л. Федунчик // Наука молода, 2013. - №19 - С. 158-165

8. Федунчик Л.Г. Реалії ринку праці України / Л.Г. Федунчик // Організаційноуправлінські та психологічні аспекти сучасного ринку праці України : тези доповідей IV Всеукр. наук.-практ. конф. студентів та аспірантів / упоряд. О.П. Канівець, Л.Г. Новаш. - К. : ІПК ДСЗУ, 2015. - С. 126-128. 